SHS Web of Conferences 24, 01012 (2016)

DOI: $10.1051 /$ shsconf/20162401012

(c) Owned by the authors, published by EDP Sciences, 2016

\title{
Construction of long-term mechanism of accurate identification and effective subsidization of poor college students
}

\author{
Feng $\mathrm{Wu}$ \\ College of Life Science and Technology, Huazhong Agricultural University, Wuhan, Hubei, China
}

\begin{abstract}
The effective implementation of accurate identification and subsidization toward poor college students is an important form to realize subsidization for educating, and an important carrier and condition of actual implementation toward the national subsidizing policy. Currently, the accuracy and fairness cannot be guaranteed in the identification and subsidization toward poor college students, the appraisal and selection process lacks objective and effective quantitative reference indicators in, the source of subsidies is narrow and problems such as "attaching great importance to subsidization, but less importance to development" exist. The problems shall be resolved by the following aspects through planning and coordination: the construction of the monitoring and accountability mechanism, the establishment of the poverty indicator system, the information construction of poor students' archives and the multi-channel financing and focusing on the effectiveness of subsidizing for educating.
\end{abstract}

Keywords: poor college students; poverty identification; subsidizing policy

\section{INTRODUCTION}

In recent years, with the increasing national investment in subsidies for poor college students, how to effectively and sufficiently use such financial resources by the colleges to guarantee successful completion of education for poor college students, help them grow up and become talents, and ultimately realize accurate identification and effective subsidization of poor college students is a major challenge for the college.

\section{INSPECTION OF CURRENT STATUS OF IDENTIFICATION AND SUBSIDIZATION OF POOR COLLEGE STUDENTS}

The mature and sound working mechanism of identification about poor college students is an important prerequisite and system guarantee to realize accurate identification and effective subsidization. In addition, to follow up education for subsidized students, carry out moral education with the integrity, gratitude, dedication, helpfulness and other socialist core values, guide to gratitude and contribute to society, achieve subsidization for educating, and practically play a role in educating by the scholarship and grants is also an important way to achieve effective subsidization of poor college students. Currently, problems such as the non-strict identification standards, the irregular identification procedures, the unclear identification results, the infringement of privacy right of students, the single source of subsidies and the students with bad faith and opportunism that exist in the identification and subsidization of poor college students seriously affect the realization of justice and fair identification and financial aid for poor college students. In addition, the current colleges and universities generally "attach great importance to subsidization, but less importance to education". Self-reliance education, cultivation of gratitude consciousness, honesty and trustworthiness education, ideal and belief education of poor college students are lack of deserved attention, which affect the expected effect of poverty subsidization.

\section{ANALYSIS ON CAUSE OF PROBLEMS IN IDENTIFICATION AND SUBSIDIZATION OF POOR COLLEGE STUDENTS}

Currently, many unscientific and irrational factors remain in the identification and subsidization of the 
poor college students, and many problems in single evidentiary material of poverty identification, false evidentiary material of poverty identification, the lack of systematic and accurate quantitative reference indicators in the identification process, a shortage of poverty subsidies, emphasis on offering substances to students, and negligence of follow-up education and cultivation of students. Next, this paper attempts to carry out in-depth cause analysis from above several aspects, so as to provide the basis for policy recommendations expressed herein.

1. Identification of poor college students fails to guarantee its accuracy and fairness

Currently, for poverty identification, the subsidizing management department in colleges and universities mainly requires students to submit family economic situation questionnaire, poverty evidentiary material and application form of poor student identification, but the main objective reference materials are the family economic situation questionnaire and the poverty evidentiary material stamped by the local government and department of civil affairs in the location of students. Due to the asymmetric information on schools and the family of students, coupled with the high cost of information screening and the presence of other objective facts, the local government and the civil affairs department do not assume any related liability for poverty identification. They are often perfunctory to stamp hastily, without rigorous examination about the real family situation of the students. Some students can easily get the evidentiary material of poverty through their relationships. Thus, it tends to encourage the non-poor students to have opportunistic mentality and fake as real poor students by the use of the system to mix the false with the genuine, so as to embezzle national subsidies and subsidized resources. In most cases, real poor college students often fail to actively apply for poverty identification because they are unfamiliar with the subsidizing policy and unwilling to be labeled with "poor students", resulting in loss of student subsidies, and deserved financial aids.

In the actual implementation process of poverty identification, the poverty situation of students mostly relies on the subjective and emotional judgment of the instructor due to a wide range of students and a large number of classes. Thus, the main reference indicator of the poverty identification of poor college students is the number of votes made by the students led by a head teacher. In the appraisal and voting in class, there is certainly "canvassing" phenomenon, that is, if a student which is on good terms with others or born in relatively affluent family is often able to win higher votes so that the scientificity and fairness of this method of poverty identification cannot be effectively guaranteed.

2. Identification of poor college students is lack of objective and effective quantitative reference indicators

On one hand, the current common practice in col- leges and universities is to classify the poor college students identified into two types by their family economic condition, namely, poverty-stricken family and somewhat underprivileged family. Such classification standard is not complete enough, coupled with restrictions of poverty identification indicators, most college students with poverty identification are classified into the group with somewhat underprivileged, while there are certainly students with different levels of practical difficulty and different situations of practical difficulty of family in the group with general difficulty. Without scientific classification of this part of group, it is unable to realize reasonable classification of the group level of poor students. On the other hand, the main reference indicator of poverty identification is the number of democratic votes of the class, which ranks from high to low. The students with votes rank the top can obtain the identification of particularly underprivileged family, while the students with votes in the bottom rank can obtain the identification of somewhat underprivileged family. Such identification fails to make a comprehensive evaluation with the factor of actual underprivileged family about any poor students and their vulnerable background. The reality classification of final difficulty identification relying on the over-generalized number of votes in the class has its one-sidedness, which is lack of systematicness and loses credibility.

3. Source of subsidies for poor college students is poor and the subsidizing effort is limited

Currently, the subsidies for poor college students in colleges and universities are mostly from the educational fund for running a school, the government allocation and the self-financing of school. In colleges and universities integrated with four functions of social services, scientific research, talent training and cultural heritage, it is almost impossible to realize higher return or just rely on the revenue to set up special grants for students. With the continuous expansion of college student enrollment in recent years, the number of college students rises in successive years, and the proportion of poor college students also increases structurally. In addition, the colleges and universities have very few special projects about student subsidies donated and set up in the name of the enterprises and public institutions in society, social groups and individuals, and fail to meet the practical and objective demands of poor college students by solely relying on the educational fund and government allocation. The colleges and universities are aware of the seriousness of the problem, but they are lack of enthusiasm and initiative for multi-channel financing and still maintain a negative attitude of "waiting, relying and demanding".

4. For poor college students, there is a phenomenon of "attaching great importance to subsidizing, but less importance to development"

The original intention for the state to set up fellowship and scholarship policy for poor college students 
is not only to help poor students complete their studies, but more importantly is to facilitate and achieve the healthy growth and overall development of the poor college students. In the actual development and policy implementation, the colleges and universities "attach importance to material support but less importance to spiritual support; attach importance to other's help but less importance to themselves; focus on granting subsidies but neglect investment in moral education; put emphasis on direct funding but neglect indirect funding; and focus on blood transfusion but ignore hematopoiesis. In the supply and support of economic substance to the students, the moral education, psychological education and gratitude education are particularly important. Otherwise, in the long run, the psychological problems of the students with economic difficulty of family are not effectively resolved. What's worse, they will gradually form the hatred toward the rich, self-pressurization, psychology of complaint, concept of "waiting, relying and demanding", weak charity awareness and lack of integrity and other bad feelings and values, moreover, these can accompany with their growth path, resulting in "psychological poverty" and other psychological burdens under the impact of such psychological imbalance and bad value. The current subsidizing mode is free of deeply guiding and educating the students to establish and practice the ideals and beliefs of self-reliance, honesty, gratitude to society, serving the motherland and contributing to the society so that they are unable to be fully cultivated in an all-around way.

\section{EXPLORATION OF PROMOTION OF SYSTEM IMPROVEMENT IN ACCURATE IDENTIFICATION AND ACCURATE SUBSIDIZING MECHANISM FOR POOR COLLEGE STUDENTS}

Based on the foregoing analysis, in the actual operational process, the effect of subsidizing policy is not strong in colleges and universities. The author believes that, the subsidization of poor college students shall be improved from the following several aspects, so as to achieve reasonable and effective, precise and accurate identification and effective subsidization of the poor college students.

1. Establish a supervision and accountability mechanism for the economic situation of the origin of poor students

Timely and accurate monitoring of the poverty information and daily consumer information in the origin of students provided by the poor college students is an important basis and reference condition to ensure fair, reasonable and effective issuance of the special national subsidies for poor college students. A serious and powerful accountability and track-down mechanism is established due to the presence of false information, false declaration and poverty identifica- tion privately by the local administration without in vestigation, so as to ensure real implementation of the national fellowship and scholarship policy and effective use of funds. On one hand, the real economic situation and consumption information of the poor college students is monitored powerfully through examining the capital consumption information of the students' one-card and bank card, poor students' family visit by the instructors and head teachers, mutual supervision of the classmates, self-supervision and other ways. Moreover, a complete and multi-element information monitoring feedback channel is established, and the dynamic management of monitoring information is strengthened, so as to ensure that the relevant unreal conditions and high consumption information is timely conveyed and updated. On the other hand, for the false identification information and high consumption situations, the school should timely recover the subsidies of related students, carry out criticism and education and seriously punish "pseudo poverty". In addition, the state should actively introduce the relevant laws and regulations, trace accountability of the relevant administration and civil affairs departments who are not serious to perform their duties and strive to create a positive, fair and just external environment for poverty identification.

2. Establish a sound and scientific quantitative indicator system for poverty identification

The colleges and universities should scientifically and systematically carry out accurate definition and reasonable planning of the poverty identification indicators and process for the poor college students so that the poverty identification basis, identification indicators and identification results are compliant, fair and reasonable. First, there is a need to change the past simple and unrealistic form of simply classifying the poor students into particularly difficult type and generally difficult type, combined with actual situations of the students, explore and establish three or more types of poverty identification for the student groups with survival difficulty life difficulty or student groups development difficulty so that the poverty classification and identification types are more realistic, intuitive and accurate; second, on the basis of scientific classification of poverty types, there is a need to actively explore and identify sub-classification conditions under each classification system so that each classification system precisely corresponds to certain sub-classification conditions. For example, the orphans and disabled students, the students suffering from a major disaster in their family, the students with serious long-term illness and other sub-classification conditions are as the secondary indicators of poverty identification for the students with survival difficulty; the single-parent students, the students with a parent who loses the basic labor ability, rural poor households and other sub-classification conditions are as the secondary reference indicators of poverty identification for the students with life difficulty; the students 
with old or chronically ill parents of low-income households in towns and cities or other sub-classification conditions are as the secondary identification indicators for the students with development difficulty; finally, there is a need to abandon the form of solely relying on the votes of classmates to determine the poverty level, and need to comprehensively refer to the democratic votes of classmates, the opinions of college tutors, head teachers and instructors, evidentiary material of poverty identification, oneself written statement, secondary actual conditions and indicators in the types of poverty identification and other reference conditions, and assign a certain percentage of values to each reference condition, and finally form a scientific and quantifiable reference point for poverty identification of each poor student.

3. Strengthen the digital management and information construction for poor students' archives

In an era of highly developed information technology and the external environment of new media, the traditional way of relying on browsing the paper archives and materials of the students and recording the actual information of poor students brings a great inconvenience and difficulty to effective implementation of subsidization and management modernization. To make the poverty subsidization more efficient, comprehensive and accurate, the establishment of online declaring system of poverty identification and dynamic management of electronic archive information is a necessary condition to achieve digital management and dynamic management of poor student information and a precise implementation of subsidization for poor students. On one hand, the poor college students identified with poverty carry out online declaration and entering electronic poverty information, so as to ensure that the personal electronic archive is complete; on the other hand, the social grants, scholarship, work-study, awards, school performance, family situation and other information of poor college students in the information library of poor students shall be updated in a timely manner, and the dynamic management is implemented, so as to provide a basis for the future subsidy adjustment decision-making and poverty subsidization effect.

4. Integrate with resources for multi-channel financing and improving efforts of poverty subsidization

The school-running funds for most colleges and universities such as Harvard University is not sponsored by the state, but donated by a majority of schoolfellows. Currently, most of school-running funds, fellowships and scholarships of Chinese universities are from government. There is a need to extensively mobilize the social community, charity organization and successful people to participate in the construction of school funding system, and build a multi-point, multi-element and multi-faceted funding system and mechanism integrated with the government force, social force, personal ability and school itself, so as to inject continuous vitality to subsidize poor college students. On one hand, the school should actively mobilize the power of alumni and alumni branches in various regions, and actively mobilize the alumni to fund to set up fellowships and scholarships; on the other hand, the school should actively explore a new form of cooperation between school and enterprise, opening up industry-university-research cooperation and strive for subsidization by the special project of fellowship. For example, the school can arrange the students who obtain enterprise fellowship to do part-time job in the enterprise in winter and summer vacation or on weekends, so as to repay the enterprise for their kindness and cultivate social practical ability and self-reliance spirit of the subsidized college students.

5. Improve the subsidization and education system, and strive to achieve equal importance of "assisting the poor and educating people" and "encouraging and strengthening ability"

While achieving material and economic assistance for poor students, the necessary ideal and belief education, integrity and gratitude education, psychological education, self-reliance education and various forms of work-study jobs can be better to motivate students from their inner world internalize or externalize diverse forms of theme education and moral education effect to the heart and guide them to develop a hard struggle, self-improvement conviction and style. First, there is a need to focus on cultural cultivation, strengthen students' gratitude and social responsibility education, carry out a great variety of Gratitude Education Month, Integrity and Gratitude Month, Psychological Education Month and a series of theme activities with rich connotation, rely on a series of activity months to highlight the theme, and mobilize participation and create an atmosphere, and express a positive, honest, thankful and self-improved school cultural atmosphere in school; second, there is a need to scientifically and rationally set up work-study posts and broaden work-study channels for poor college students, so as to provide a platform to enhance their operational ability. And there is also a need to focus on ability training of poor work-study student group, regularly carry out training for assisting management team, answers doubts in work, summarize deficiency in work, guide the poor students with "blood transfusion type of materials" into the poor students with "hematopoiesis type of skills", and ultimately enhance their ability to work and cultivate their sense of self-reliance, and realize the effect of subsidizing for educating; finally, regularly carry out self-appraisal of the subsidized poor students. The appraisal content covers learning performance, voluntary services, recent performance, subsidized feelings and future planning. Thus, the poor college students with gratitude are guided to establish their ideal and work hard to be excellent college students with real comprehensive development. 
SSHE 2015

\section{REFERENCES}

[1] Gao, jianmin. 2003. A Review of American Federal Financial Support for Education in Recent Years. Comparative Education Review, 2003(8)
[2] Chen Jie, Jia Ping \& Zhang Feng. 2009. New discussion of subsidizing mode of poor college students. Higher Agricultural Education. (9)

[3] National Long-and-mid-term Education Reform and Development Outline (2010-2020). Beijing: China Legal Publishing House, 2010. 